\title{
DIVERSITY AND SEASONAL FLUCTUATION OF THRIPS SPECIES ON YELLOW TREE LUPIN (LUPINUS ARBOREUS)
}

\author{
S. $\mathrm{HE}^{1}, \mathrm{M}-\mathrm{C}$. NIELSEN ${ }^{2}$ and L.L. FAGAN ${ }^{2}$ \\ ${ }^{1}$ Bio-Protection and Ecology Division, Lincoln University, Lincoln, Canterbury, \\ New Zealand \\ ${ }^{2}$ Plant \& Food Research, Private Bag 4704, Christchurch, New Zealand \\ Corresponding author: FaganL@crop.cri.nz
}

\begin{abstract}
Yellow tree lupin (Lupinus arboreus), an abundant weed in New Zealand, is host to several economically important thrips species. The diversity and relative abundance of thrips found on yellow tree lupin were measured weekly via hand-collections over the 2008/09 summer at two locations in Canterbury separated by $8 \mathrm{~km}$. From the 1540 thrips that were collected and slide-mounted, eight thrips species were identified. The most abundant species was New Zealand flower thrips (Thrips obscuratus), followed by onion thrips (Thrips tabaci), the lupin strain of western flower thrips (Frankliniella occidentalis), Thrips vulgatissimus, Thrips australis, Limothrips cerealium, Chirothrips manicatus and Tenothrips frici. The largest variation in relative abundance occurred in early December, with onion thrips dominant at Killinchy and western flower thrips dominant at Rakaia. In late December at Rakaia, the dominant species shifted to New Zealand flower thrips. This indicates considerable spatial and temporal variation in relative abundance of thrips species. Keywords: western flowers thrips, Frankliniella occidentalis, New Zealand flower thrips, Thrips obscuratus, onion thrips, Thrips tabaci, seasonal fluctuation.
\end{abstract}

\section{INTRODUCTION}

Of the 5000 species of thrips (Order: Thysanoptera) described worldwide, 51 species in the Suborder Terebrantia and 68 species in the Suborder Tubulifera have been recorded in New Zealand (Mound \& Walker 1982, 1986), and this number continues to increase as more exotic thrips species become established (Teulon \& Neilsen 2005). Over 60\% of Tubulifera species are endemic to New Zealand and mainly feed on fungi (Mound $\&$ Walker 1986), with only a few species causing damage to crops (Moritz et al. 2001). By contrast, most species of Terebrantia are introduced to New Zealand (Mound \& Walker 1982) and feed both on host plants introduced from their native range and on indigenous New Zealand plant species (Teulon \& Penman 1990). The family Thripidae (Terebrantia), in particular, contains several introduced polyphagous thrips species (e.g. onion thrips, T. tabaci Lindeman and western flower thrips, F. occidentalis (Pergande)), which are serious pests causing damage to many agricultural, ornamental, plantation and forestry commodities by feeding, oviposition or tospovirus transmission (Lewis 1997). Research on host plants of phytophagous thrips is essential for understanding their biological significance (Martin \& Mound 2004). Lupinus arboreus Sims (yellow tree lupin) is an invasive weed that is extremely abundant in New Zealand (Williams \& Timmins 1990) and is known to be a host plant of T. obscuratus (Crawford) (New Zealand flower thrips) and of the lupin strain of western flower thrips (Mound \& Walker 1982; Teulon \& Penman 1990). 
New Zealand flower thrips is a key stonefruit pest that is endemic to New Zealand, and is polyphagous, feeding on more than 225 plant species of 78 families and 177 genera, including many introduced plants and weeds (Teulon \& Penman 1990). The lupin strain of the western flower thrips was introduced into New Zealand more than 70 years ago (Mound \& Walker 1982). Unlike the greenhouse strain of the western flower thrips, it is mainly restricted to yellow tree lupin and is not known to cause any economic loss to commercial crops (Mound \& Walker 1982; Martin \& Workman 1994; Mound 2005). Although the relative abundance and flight activity of these two species has been recorded in Canterbury using water traps and suction traps in both orchards and vegetable fields (e.g. Teulon \& Penman 1996; Nielsen et al. 2004), no host plant-specific population data are available for yellow tree lupin. Previous field work has shown that both species are abundant at different flowering stages of yellow tree lupin host plants (M-C. Nielsen, unpubl. data).

The main objectives of this study were to estimate thrips diversity on yellow tree lupin and to measure seasonal fluctuations in their relative abundance. New Zealand flower thrips and the lupin strain of western flower thrips were expected to be the dominant thrips species on yellow tree lupin, and it was predicted that the seasonality of these two species would be similar on the same host plant.

\section{Thrips collection}

\section{METHODS}

A random selection of yellow tree lupin branches (flowers, seeds and/or leaves) were collected weekly at two locations in Canterbury and brought back to the laboratory at Plant \& Food Research, Lincoln, for processing. On farmland at Killinchy $\left(43^{\circ} 45^{\prime} \mathrm{S}\right.$, $172^{\circ} 17^{\prime} \mathrm{E}$ ), material was collected from 31 October 2008 - 14 January 2009 , and near the Rakaia river bed $\left(43^{\circ} 44^{\prime} \mathrm{S}, 172^{\circ} 01^{\prime} \mathrm{E}\right)$ the collection was from 17 November 2008 - 16 January 2009. Collection dates varied between the two locations within the same collection week, as did the size, age and number of branches collected from each host plant, resulting in differences in the total numbers collected but not in the species of thrips found. Adult thrips were extracted from lupins by beating the branches, flower heads, leaves and seeds over a white plastic tray $(450 \times 340 \mathrm{~mm})$. The thrips that fell onto the tray were then individually collected using a fine paint brush and transferred into vials filled with $75 \%$ ethanol and total numbers recorded.

\section{Thrips identification}

The collected thrips were mounted onto glass microscope slides for identification. Where $>100$ thrips were collected, 100 specimens were mounted and for all other samples all collected thrips were mounted. The total number of each thrips species in each sample was estimated using the proportions found in the sub-samples. The mounted thrips were identified to species and sex under a compound microscope, following Mound \& Walker (1982).

\section{Thrips diversity on yellow tree lupins}

\section{RESULTS}

Both Terebrantia and Tubulifera species were found on yellow tree lupins collected at the two sites (Table 1). A total of 1515 Terebrantia thrips were mounted onto glass slides for identification. Eight Terebrantia species were identified, all belonging to the family Thripidae, subfamily Thripinae. Overall, New Zealand flower thrips (including both females and males) was the most abundant species $(34.4 \%)$, followed by onion thrips $(31.2 \%)$, western flower thrips $(27.4 \%)$ and T. vulgatissimus $(4.4 \%)$ (Table 1). However, the relative abundance of the species varied between the two collection sites. Onion thrips was the most abundant species at Killinchy, with $67.2 \%$ of the total number of thrips collected at this location, whereas New Zealand flower thrips, T. vulgatissimus and western flower thrips had $16.0 \%, 9.2 \%$ and $3.2 \%$ of total abundance, respectively. By contrast, at the Rakaia site, New Zealand flower thrips and western flower thrips dominated, with $49.5 \%$ and $47.5 \%$ of the total number of thrips collected, respectively, 
whereas onion thrips and T. vulgatissimus only accounted for $2.0 \%$ and $0.4 \%$ of total abundance, respectively.

TABLE 1: Total abundance of thrips species collected from yellow tree lupins over a summer period (31 October 2008 - 16 January 2009) at two locations (Killinchy farmland and Rakaia river) in Canterbury, New Zealand. Species are listed in order of most to least abundant.

\begin{tabular}{|c|c|c|c|c|c|}
\hline \multirow[b]{2}{*}{ Species name } & \multicolumn{2}{|c|}{ Killinchy } & \multicolumn{2}{|c|}{ Rakaia } & \multirow[b]{2}{*}{$\begin{array}{c}\text { Total } \\
\text { No. }\end{array}$} \\
\hline & 우 & $\sigma^{\pi}$ & q & $\sigma^{x}$ & \\
\hline \multicolumn{6}{|l|}{ Terebrantia: } \\
\hline Thrips obscuratus (Crawford 1941) & 75 & 37 & 358 & 59 & 529 \\
\hline Thrips tabaci Lindeman 1888 & 469 & 0 & 17 & 0 & 486 \\
\hline Frankliniella occidentalis (Pergande 1895) & 17 & 5 & 317 & 83 & 422 \\
\hline Thrips vulgatissimus Haliday 1836 & 64 & 0 & 3 & 0 & 67 \\
\hline Tenothrips frici (Uzel 1895) & 5 & 0 & 0 & 0 & 5 \\
\hline Limothrips cerealium (Haliday 1836) & 3 & 0 & 0 & 0 & 3 \\
\hline Thrips australis (Bagnell 1915) & 0 & 1 & 1 & 0 & 2 \\
\hline Chirothrips manicatus (Haliday 1836) & 0 & 0 & 0 & 1 & 1 \\
\hline Tubulifera spp. & \multicolumn{2}{|c|}{22} & \multicolumn{2}{|c|}{3} & 25 \\
\hline Total & \multicolumn{2}{|c|}{698} & \multicolumn{2}{|c|}{842} & 1540 \\
\hline
\end{tabular}

Two species, L. cerealium and T. frici, were found only at Killinchy, and C. manicatus was found only at Rakaia. No male thrips were present for onion thrips, T. vulgatissimus, T. frici or L. cerealium. A single wingless form of C. manicatus was also found at Rakaia.

Seasonal fluctuations of the most abundant thrips species on yellow tree lupins

At Killinchy, onion thrips was the dominant species on yellow tree lupin during the whole survey period, except in early November when the relative abundance of New Zealand flower thrips marginally exceeded that of onion thrips (Fig. 1a). Thrips vulgatissimus showed a moderately high proportion of total abundance (up to 20\%) in spring, from October to December. The relative abundance of western flower thrips was consistently low throughout the season at Killinchy (Fig. 1a). At Killinchy the sex ratios $\left(\sigma^{7}: Q_{)}\right)$of New Zealand flower thrips and western flower thrips were about 1:2 and 1:3 respectively, throughout the season.

At the Rakaia river site, the relative abundance of New Zealand flower thrips was greatest from late November to early December, during the first flowering (Fig. 1b). Relative abundance declined sharply when the first flowering ended and lupin plants began to bear seeds from early December, while western flower thrips became the dominant thrips species by the second flowering (in late December). The sex ratios ( $\sigma^{7}:$ O $)$ of New Zealand flower thrips and western flower thrips were about 1:6 and 1:4, respectively, throughout the season.

The trends for proportion of each of the three main thrips species collected from yellow tree lupins over the summer period (Fig. 1) were similar to the trends for thrips densities. The density of onion thrips was highest at Killinchy and lowest at Rakaia throughout the season. The density of New Zealand flower thrips abruptly decreased while the density of western flower thrips increased from late December at both sites. 

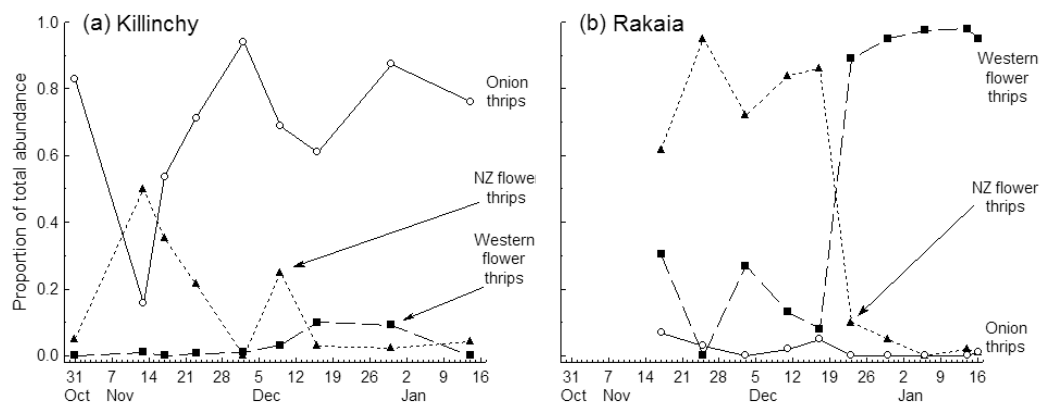

FIGURE 1: The proportion of each of the three main thrips species collected from yellow tree lupins over a summer period (31 October 2008 - 16 January 2009) at two locations, (a) Killinchy farmland and (b) Rakaia river, in Canterbury, New Zealand.

\section{DISCUSSION}

Although thrips species are known to be common on yellow tree lupin in the Canterbury region (Teulon et al 2005; Teulon \& Neilsen 2005), host-plant feeding associations with lupin have only been previously recorded for New Zealand flower thrips and the lupin strain of western flower thrips (Mound \& Walker 1982; Teulon \& Penman 1990). However, in the present study a much greater diversity of thrips species on yellow tree lupin was found than anticipated, with eight species of Terebrantia and one or more unidentified species of Tubulifera. Host-plant feeding associations have not been fully resolved for all of these species as some may be transient species dispersing from the surrounding landscape, but at least two species (onion thrips and T. vulgatissimus) had significant total capture rates, and warrant further investigation of host feeding associations.

In general, the relative proportions of species collected from yellow tree lupins across both sites combined (Table 1) were fairly typical of the overall relative proportions of species captured in flight activity traps in Canterbury, such as suction traps and water traps (Teulon \& Penman 1996), with New Zealand flower thrips and onion thrips being the dominant species collected, followed by several less abundant species. This tends to suggest that generalised activity-based sampling methods that capture dispersing thrips may be a useful measure of the relative abundance and seasonal variation in thrips populations on individual host plant species. Naturally, there are some host plant-specific differences in relative abundance that can be expected to differ from generalised trapping methods, such as the high relative abundance of the lupin strain of western flower thrips on yellow tree lupin (Neilsen 2006).

What was most surprising in the present study was that the seemingly fairly 'typical' thrips fauna recorded in the combined data set actually masked large differences in thrips relative abundances on two lupin populations that were located only $8.4 \mathrm{~km}$ apart. Initially, New Zealand flower thrips and the lupin strain of western flower thrips were expected to be the dominant thrips species on yellow tree lupin at all sites (Neilsen 2006), but in fact onions thrips were dominant at the Killinchy site throughout the season. At the Rakaia river site, patterns of relative thrips abundance were more similar to what might have been expected from past studies of thrips on yellow tree lupin (M-C. Nielsen, pers. comm.). Yellow tree lupin generally begins to bloom in October and continues until May, with a second flowering taking place from December onwards. New Zealand flower thrips was dominant on yellow tree lupin early in November and December during the first flowering, but there was a rapid and complete shift in dominance 
from New Zealand flower thrips to western flower thrips in December (see Fig. 1b), corresponding to the main period of seed production and the second minor flowering. There was also a weak suggestion of the same shift in relative abundance of these two species occurring at Killinchy (see Fig. 1a). A possible reason for the abrupt change in the relative abundance of New Zealand flower thrips and western flower thrips later in the season may be the varying nutritional requirements of different thrips species (Mound 2005). There may also be a strong interspecific competition for flower resources, and western flower thrips may only be able to dominate later in the season because they are able to maintain populations on lower-quality plant tissues by using alternative prey, such as mite eggs (Agrawal et al. 1999). However, a decline in the New Zealand flower thrips relative abundance may also be due to a decline in its population, thus dispersal of the species is likely a more important factor rather than changes in the host plant or nutritional requirements of the thrips.

The decline in relative abundance of New Zealand flower thrips on yellow tree lupin corresponded to the peak dispersal of New Zealand flower thrips captured in activity traps in Canterbury during the December-January period (Teulon \& Penman 1996; Nielsen et al. 2004). The same pattern was found on grape plants during the flowering period at two vineyards in Canterbury and the Nelson region (Schmidt et al. 2006). It has been suggested in previous studies, that since populations of New Zealand flower thrips did not develop in the agricultural crops themselves, then weed populations such as gorse and broom outside of these areas might have acted as reservoirs for large populations of New Zealand flower thrips (Teulon et al. 2005). Yellow tree lupin may represent one such reservoir host for pest thrips species in Canterbury.

The two sample locations differ in several environmental characteristics, with the Rakaia river site being a less managed site subject to periodic flooding, whereas the Killinchy site is surrounded by cultivated land. Onion thrips, which had a high relative abundance at Killinchy, are known to dominate in intensive cropping areas, particularly where Allium spp. are grown. Thrips populations may also be affected by differences in temperature, precipitation and/or soil moisture levels (Evans 1934; Teulon \& Penman 1996; Morsello et al. 2008). These results imply that the landscape elements surrounding each site may have a very strong effect on thrips populations (den Belder et al. 2003), with weed species such as yellow tree lupin acting as reservoir hosts for crop pest species during inter-crop periods. Further study at a range of different sites would help discern the full range of variation in the relative abundance of thrips species on yellow tree lupin throughout Canterbury.

In conclusion, there was a surprisingly high diversity of thrips species captured on yellow tree lupin, and striking variation in the relative abundance of species between sites just $8.4 \mathrm{~km}$ apart. This suggests that separate host-plant populations of invasive weeds cannot all be treated the same in terms of the degree to which they provide a reservoir of pest thrips in the landscape, although it is recognised that a plant species cannot be defined as a host plant for insects simply based on the presence of adult thrips (Martin $\&$ Mound 2004). Further study to determine the host status of yellow tree lupins for the other species of thrips recorded here would be beneficial.

\section{ACKNOWLEDGEMENTS}

We thank Daniel Park and Ruth Butler from Plant \& Food Research for providing comments as well as the owners of Hinau Farm for access to their property.

\section{REFERENCES}

Agrawal AA, C Kobayashi, JS Thaler 1999. Influence of prey availability and induced host-plant resistance on omnivory by western flower thrips. Ecology 80: 518523.

den Belder E, Elderson J, Schelling G, van den Brink WJ 2003. Thrips densities in organic leek fields in relation to the surrounding landscapes. Landscape Management for Functional Biodiversity 26(4): 31-36. 
Evans JW 1934. Thrips investigation. 2. Some factors that regulate the abundance of Thrips imaginis Bagnall. Annual report of the Council for Scientific and Industrial Research (Australia) 7: 62-69.

Lewis T 1997. Pest Thrips in Perspective. In: Lewis T ed. Thrips as Crop Pests. University Press, Cambridge, UK. 740 p.

Martin NA, Workman PJ 1994. Confirmation of a pesticide-resistant strain of western flower thrips in New Zealand. Proceedings of the $47^{\text {th }}$ New Zealand Plant Protection Conference: 144-148.

Martin NA, Mound LA 2004. Host plants for some New Zealand thrips (Thysanoptera: Terebrantia). New Zealand Entomologist 27: 119-123.

Moritz G, Mound LA, Morris D 2001. ThripsID: pest thrips of the world [CD-ROM]. Australian Centre for International Agricultural Research (ACIAR), Canberra, Australia.

Morsello SC, Groves RL, Nault BA, Kennedy GG 2008. Temperature and precipitation affect seasonal patterns of dispersing tobaccos thrips, Frankliniella fusca, and onion thrips, Thrips tabaci (Thysanoptera: Thripidae) caught on sticky traps. Environmental Entomology 37: 79-86.

Mound LA, Walker AK 1982. Fauna of New Zealand, Number 1, Terebrantia (Insecta: Thysanoptera). Science Information Publishing Centre, Wellington, New Zealand.

Mound LA, Walker AK 1986. Fauna of New Zealand, Number 10. Tubulifera (Insecta: Thysanoptera). Science Information Publishing Centre, Wellington, New Zealand.

Mound LA 2005. Thysanoptera: diversity and interactions. Annual Review of Entomology 50: 247-269.

Nielson M-C, Fletcher CD, Teulon DAJ 2004. Monitoring thrips flight with 7.5 metre high suction traps.New Zealand Plant Protection 57: 339 (Abstract only).

Nielson M-C 2006. Comparative life history studies of Frankliniella occidentalis (Thysanoptera: Thripidae) strains in New Zealand. Masters thesis, Lincoln University, Christchurch, New Zealand.

Schmidt K, Teulon DAJ, Jaspers MV 2006. Phenology of the New Zealand flower thrips (Thrips obscuratus) in two vineyards. New Zealand Plant Protection 59: 323-329.

Teulon DAJ, Penman DR 1990. Host records for the New Zealand flower thrips (Thrips obscuratus (Crawford) Thysanoptera: Thripidae). New Zealand Entomologist 13: 46-51.

Teulon DAJ, Penman DR 1996. Thrips (Thysanoptera) seasonal flight activity and infestation of ripe stonefruit in Canterbury, New Zealand. Horticultural Entomology 59 (3): 721-733.

Teulon DAJ, Neilsen M-C 2005. Distribution of western (glasshouse strain) and intonsa flower thrips in New Zealand. New Zealand Plant Protection 58: 208-212.

Teulon DAJ, Marroni MV, Neilsen M-C 2005. Are high country weeds the source of New Zealand flower thrips on crop plants in spring? New Zealand Plant Protection 58: 324 (Abstract only).

Williams PA, Timmins SM 1990. Weeds in New Zealand protected natural areas: a review for the Department of Conservation. Science \& Research Series (New Zealand Department of Conservation) No. 14, Wellington, New Zealand. 